\title{
L-Karnitin ve Alfa-Lipoik Asitin, HCT 116 +/+ ve -/- Kolon Kanser Hücre Serilerinin Proliferasyonu Üzerindeki Sinerjetik Etkileri
}

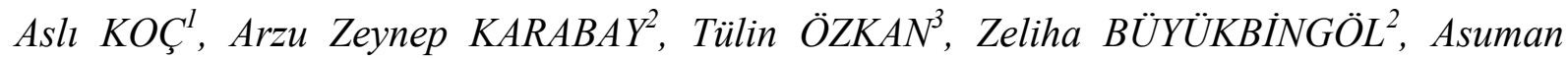 \\ SUNGUROĞLU $U^{2}$, Fügen AKTAN ${ }^{2}$
}

${ }^{\text {I} A n k a r a ~ U ̈ n i v e r s i t e s i, ~ E c z a c l l k ~ F a k u ̈ l t e s i, ~ M e r k e z ~ L a b o r a t u v a r l, ~ A n k a r a, ~ T u ̈ r k i y e ~}$

${ }^{2}$ Ankara Üniversitesi, Eczacıllk Fakültesi, Biyokimya Anabilim Dall, Ankara, Türkiye

${ }^{3}$ Ankara Üniversitesi, Tip Fakültesi, Tıbbi Biyoloji Anabilim Dal, Ankara, Türkiye

aslikoc79@gmail.com

\begin{abstract}
Özet
L-karnitin, uzun zincirli yağ asitlerinin mitokondri matriksine transportunda yer alarak, lipid metabolizmasında önemli görevlere sahip olan bir molekül olmasının yanı sıra, serbest radikal temizleyici aktivite gösterir ve antikanser özellikler sergiler. $\alpha$-Lipoik asitin, tip2 diyabet, ateroskleroz, inflamatuar deri hastalıkları ve Parkinson hastalığına karşı oldukça etkili bir molekül olduğu gösterilmiştir ve farklı kanser hücrelerinde apoptotik etkiler gösterdiği bilinmektedir. Bu çalışmada, $\alpha$-Lipoik asit ve L-Karnitin'in, HCT $116+/+$ ve HCT 116 -/- kolon kanseri hücre serilerindeki sinerjetik etkileri araştırılmıştır. Bu amaçla, HCT $116+/+$ ve -/- kolon kanseri hücreleri, L-karnitin ve $\alpha$-Lipoik asit ile 24 saat muamele edildikten sonra, MTT testi ve kaspaz 3-enzim aktivitesi ile hücre canlılı̆g 1 ve kaspaz-3 enzim aktivitesi üzerindeki etkileri incelenmiştir. Bu çalı̧̧mada, $\alpha$-Lipoik asit ve Lkarnitin'in, kombinasyon halinde verildiklerinde sinerjetik etkiler sergileyerek, HCT 116 +/+ ve -/- kolon kanseri hücrelerinin canlılığını azalttıkları ve kaspaz-3 enzim aktivitesini artırdıkları görülmüştür. L-karnitin ve $\alpha$-Lipoik asitin kanser terapisindeki sinerjetik etkilerinin mekanizmasını açığa çıkarmak için daha ileri çalışmalar yapılmalıdır.
\end{abstract}

Anahtar Sözcükler: L-karnitin, $\alpha$-lipoik asit, kolon kanseri 


\begin{abstract}
It is an effective antioxidant molecule that exhibits free radical scavenging activity and it enhances antioxidant status in rats and exhibited anticancer properties. It has been shown that $\alpha$-Lipoic acid is a very effective molecule against type 2 diabetes, atherosclerosis, inflammatory skin diseases, reperfusion arrhythmias and Parkinson's disease and serves apoptotic action in different cancer cells. These molecules can display important roles in treatment of colon cancer. In this study, we examined the synergetic effects of $\alpha$-lipoic acid and L-carnitine on HCT $116+/+$ and HCT 116 -/- colon cancer cell line. For this purpose, HCT $116+/+$ and -/- colon cancer cells were treated with L-carnitine and $\alpha$-Lipoic acid for 24 hours and MTT assay and caspase 3 enzyme activity assay was conducted. $\alpha$-Lipoic acid and L-carnitine alone or in combination decreased cell viability in HCT $116+/+$ and /- colon cancer cells and exhibited synergetic effect on the cell viability. Further studies must be conducted to find out the mechanism of their effects in cancer therapy.
\end{abstract}

Keywords: L-carnitine, $\alpha$-lipoic acid, colon cancer

\title{
Giriş
}

Kolorektal kanser, en yaygın görülen epitelial kanserlerden biridir (Tenesa, 2009). Karsinogenez ve kemeoresistansa katk1 sağlayan apoptotik hücre ölümüne direnç, kolorektal kanserin önemli bir özelliğidir (Hanahan, 2011). Kolorektal kanser hücreleri, besin yetersizliği ve hipoksi gibi tümör mikroçevresinin zor koşulları altında hayatta kalabilmek için, çeşitli adaptif mekanizmalar geliştirirler (Huang, 2015). Bu sebeple, tümör hücrelerinde apoptozun indüksiyonu, kolorektal kanserin tedavisinde potansiyel bir mekanizmadır.

L-karnitin, inflamatuar cevap mekanizmalarını modüle ettiği iyi bilinen ve kanser kaşeksinin oluşumunda önemli rol oynayan bir moleküldür (Liu, 2011).

Oksidatif stres ve apoptoz regülasyonundaki düzensizlikler, kanser hücrelerinde nedensel etkilere sahiptir (Behrend, 2003). Kanserde, $\alpha$-lipoik asit, ROS oluşumunun inhibisyonu, metal iyonlarının şelatlanması, GSH seviyelerinde (Rochette et al. 2013) ve glutatyon peroksidaz aktivitesinde artış, oksidatif stresde düşüş (Mantovani, 2003, Mizuno, 1994) aracılı̆̆ıyla pek çok antioksidan özellik sergiler ve tümör hücrelerinin ölümüne neden olarak antikanser etkiler gösterir (Dörsam, 2014). HT29 kolon kanser hücrelerinde $\alpha$-lipoik asit ve dihidroksilipoik asitin apoptozu efektif olarak tetiklediği gösterilmiştir (Wenzel, 2005). $\alpha$-lipoik asit, MCF-7 meme kanseri hücreleri, HepG2 hepatoma (Simbula et al. 2007), Jurkat T- lemfoma hücreleri (van de Mark, 2003) gibi pek çok hücre tipinde proapoptotik etkiler sergiler (Dozio, 2010). Bu çalışmada, $\alpha$-lipoik asit ve L-karnitin'in yalnız ve kombinasyon halinde, HCT 116 +/+ and HCT 116 -/- kolon kanser hücrelerinde sitotoksik etkileri değerlendirilmiştir. $\alpha$-lipoik asit ve L-karinitin'in kombinasyon halinde verildiğinde, yalnız verildikleri duruma göre, HCT 116 +/+ ve HCT 116 -/- hücrelerinin proliferasyonu ve apoptozu üzerinde daha etkili oldukları görülmüştür. 


\section{Gereç ve Yöntem}

\section{Hücre Kültürü}

HCT +/+ ve HCT -/- kolon kanseri hücre serileri Prof. Dr. Bert Vogestein'den temin edildi. Hücreler, $75 \mathrm{~cm}^{2}$ flasklarda, $\% 10$ 1s1 ile inaktive edilmiş fetal sı̆̆ır serumu, \%1 penisilin/streptomisin, \%1 glutamin içeren RPMI 1640 besiyerinde, $37^{\circ} \mathrm{C}$ 'de $\% 5 \mathrm{CO}_{2}$ ve $\% 95 \mathrm{O}_{2}$ içeren inkübatörde kültüre edildi. Besiyeri hazırlanmadan önce, steril sığır serumu, $60{ }^{\circ} \mathrm{C}$ su banyosunda, 30 dakika inaktive edildi. Hücreler \%80 konfluent olduğunda, hücre kazıyıcısı ile kazındı. Hücre sayımı, tripan mavisi ile yapıldı ve 96'lık ve 6'lık plaklara eşit sayıda hücre ekildi. Bir gece inkübasyonun ardından, L-karnitin, $\alpha$ - Lipoik asit ve L-karnitin/ $\alpha$ - Lipoik asit ile 24 saat inkübe edildi.

\section{Hücre Canlığının Belirlenmesi}

Sitotoksisite deneyleri, kololorimetrik 3-(4,5-dimetil thiazol-2yl)-2,5-difenil tetrazolyum bromide (MTT) analizi ile yapıldı. Hücreler, $37^{\circ} \mathrm{C}$ 'de $0,5 \mathrm{mg} / \mathrm{ml}$ MTT ile 1 saat inkübe edildikten sonra, besiyeri atıldı ve çözünmeyen formazan kristalleri, DMSO'da çözüldü. MTT redüksiyonu, 550 ve 690 nm'de absorbansın ölçülmesi ile belirlendi. Canlılık (\%) kontrole oranlanarak hesaplandı.

\section{Kaspaz-3 Enzim Aktivitesinin Belirlenmesi}

Sitosolik hücre ekstraktları ( $20 \mu \mathrm{g}$ protein) kaspaz-3 substratı ile bir saat inkübe edildi ve oluşan floresan ürün florometrede (Perkin-Elmer LS55, Waltham, MA), $340 \mathrm{~nm}$ eksitasyon ve $460 \mathrm{~nm}$ emisyon dalga boyunda (Alexis Biochemicals instructions) ölçüldü ve relatif floresans $\mu \mathrm{g}$ protein başına hesapland.

\section{Protein Tayini}

Örneklerin protein tayini Bradford metoduna göre hesaplandı. 96 kuyucuklu plaklarda, 195 $\mu 1$ Bradford ajanı (Bio-rad) ve $5 \mu \mathrm{l}$ örnek $5 \mathrm{dk}$ karanlıkta inkübe edildikten sonra spektrofotometrede (Molecular Devices-Spectra Max) optik dansite ölçümü yapıldı ve BSA standartları ile hazırlanan protein standart grafiği kullanılarak hücre lizatlarının protein seviyeleri hesaplandı.

\section{İstatistiksel Analiz}

En az üç bağımsız denemeden elde edilen sonuçlar ortalama \pm standart sapma olarak ifade edildi. İstatiksel analiz one-way ANOVA testi ile yapıldı. $\mathrm{P}<0,05$ değeri istatistiksel olarak anlamlı kabul edildi.

\section{Bulgular}

HCT 116 p53 +/+ hücreleri, L-karnitin $(7,5 \mathrm{mM})$ ve $\alpha$-lipoik asit $(5 \mathrm{mM})$ ile ayrı ayrı ve kombinasyon halinde 24 saat inkübe edildikten sonra, hücre canlılığında meydana gelen \% değişimler belirlenip sonuçlar şekil 1'de gösterilmiştir (Şekil 1). 


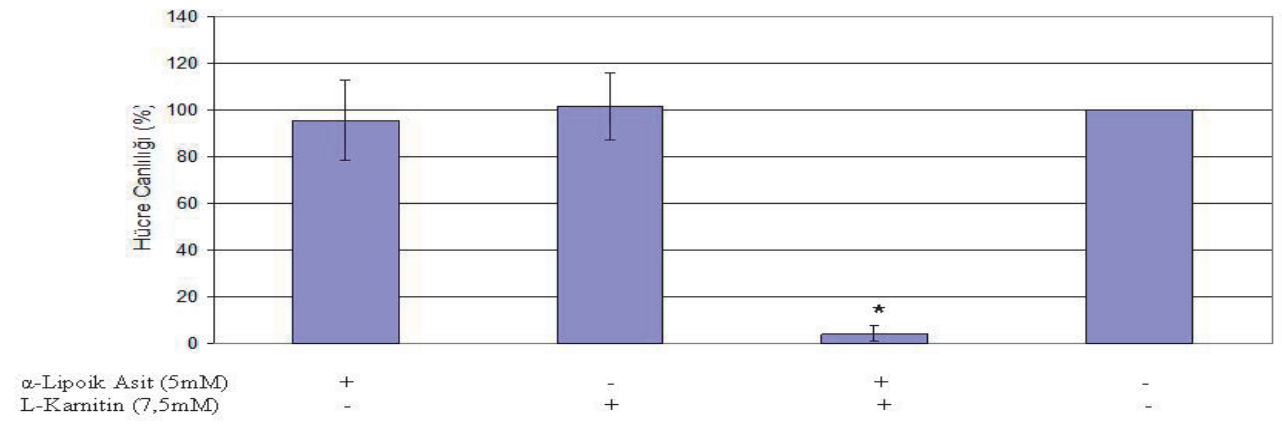

Şekil 1. HCT +/+ hücre serilerinde $\alpha$ - lipoik asit ve L-karnitin'in hücre canlllığı üzerindeki etkileri

L-karnitin $(7,5 \mathrm{mM})$ ve $\alpha$ - lipoik asit $(5 \mathrm{mM})$ yalnız başlarına uygulandıklarında hücre canlılığında anlamlı derecede azalmaya sebep olmazken, kombinasyon halinde uygulandıklarında, hücre canlılığını anlamlı düzeyde azalttıkları görülmüştür $(\mathrm{p}<0,05)$.

HCT 116 p53 -/- hücre serileri, L-karnitin ve $\alpha$-lipoik asit ile ayrı ayrı ve kombinasyon halinde 24 saat inkübe edildikten sonra, hücre canlılığında meydana gelen değişimlerin yüzdesi belirlenmiştir (Şekil 2). L-karnitin HCT -/- hücrelerinde hem tek başına hem de $\alpha$ - lipoik asit ile kombinasyon halinde verildiğinde, hücre canlılığını azaltmıştır ve $\alpha$-lipoik asit ile beraber uygulandığında, L-karnitinin hücre canlılı̆̆ını inhibe edici etkisi artmaktadır. $\alpha$-lipoik asit ise tek başına, hücre canlılığında anlamlı azalmaya neden olmazken, L-karnitin ile beraber uygunlandığında hücre canlılığını anlamı derecede azalttığı görülmüştür $(\mathrm{p}<0,05)$.

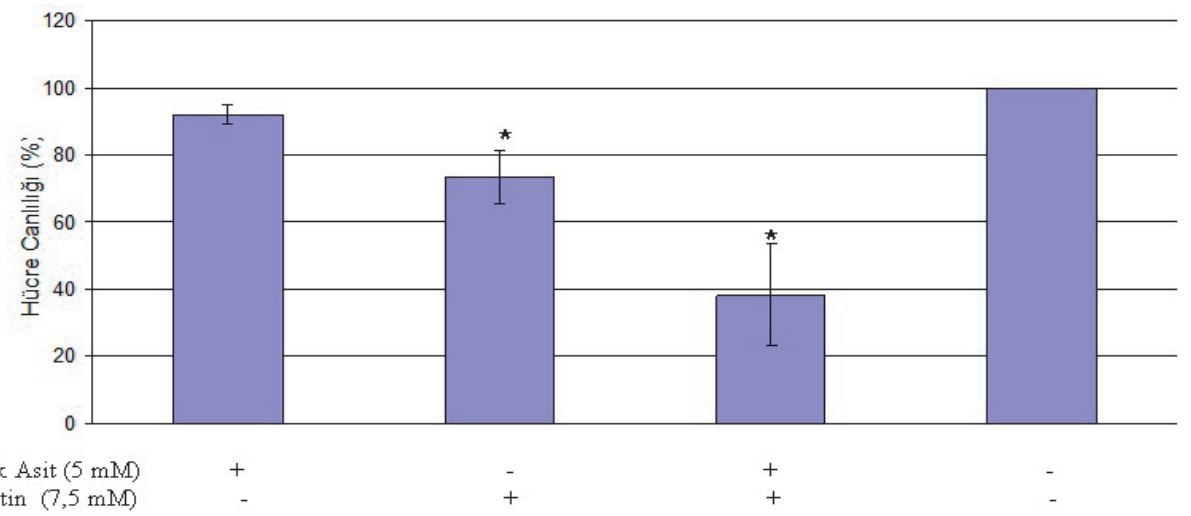

Şekil 2. HCT 116 -/- hücre serilerinde $\alpha$ - lipoik asit ve L-karnitin'in hücre canlılı̆̆l üzerindeki etkileri

Kaspaz 3 enzim aktivitesinin belirlenmesi amaciyla, HCT $116+/+$ hücreleri, L-karnitin ve $\alpha$-lipoik asit ile ayrı ayrı ve kombinasyon halinde 24 saat inkübe edildikten sonra, kit protokolüne uygun bir şekilde, sitosolik ekstraksiyon ve ardından sitosolik hücre ekstraktlarında, protein miktar tayini yapıldı ve eşit miktarda protein içeren sitosolik lizatlar (20 $\mu$ g protein), kaspaz-3 substratı ile bir saat inkübe edildi. +/+ hücrelerde elde edilen kaspaz 3 aktivitesi sonuçları şekil 3'de, -/- hücrelerde elde edilen sonuçlar şekil 4'de gösterilmiştir (Şekil 3 ve şekil 4). 


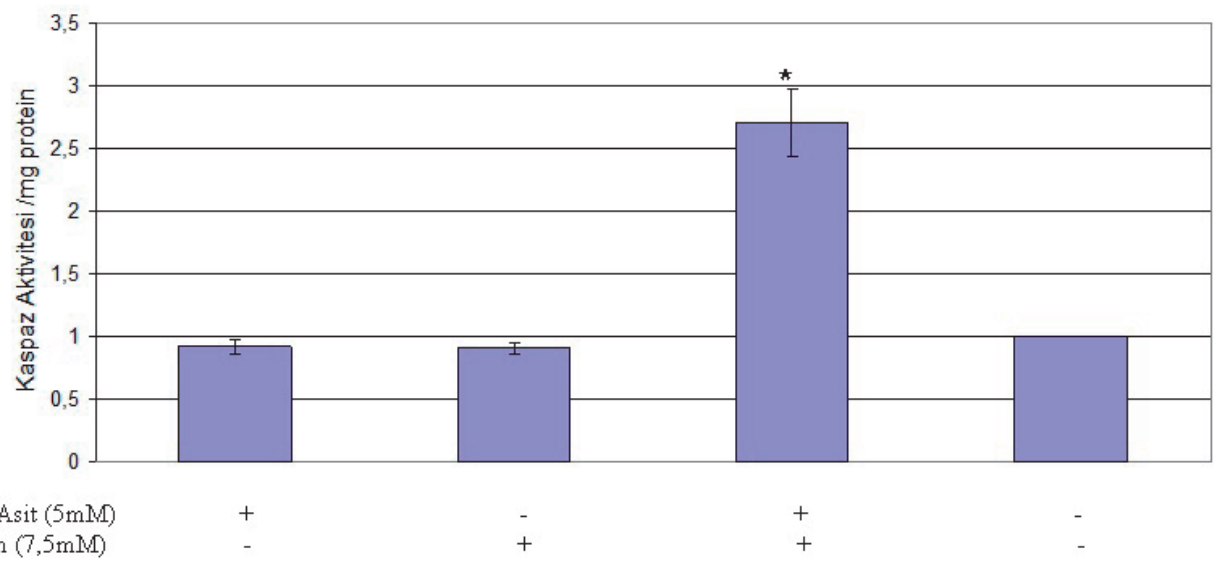

Şekil 3. HCT +/+ hücre serilerinde $\alpha$ - lipoik asit ve L-karnitin 'in kaspaz-3 enzim aktivitesi üzerindeki etkileri

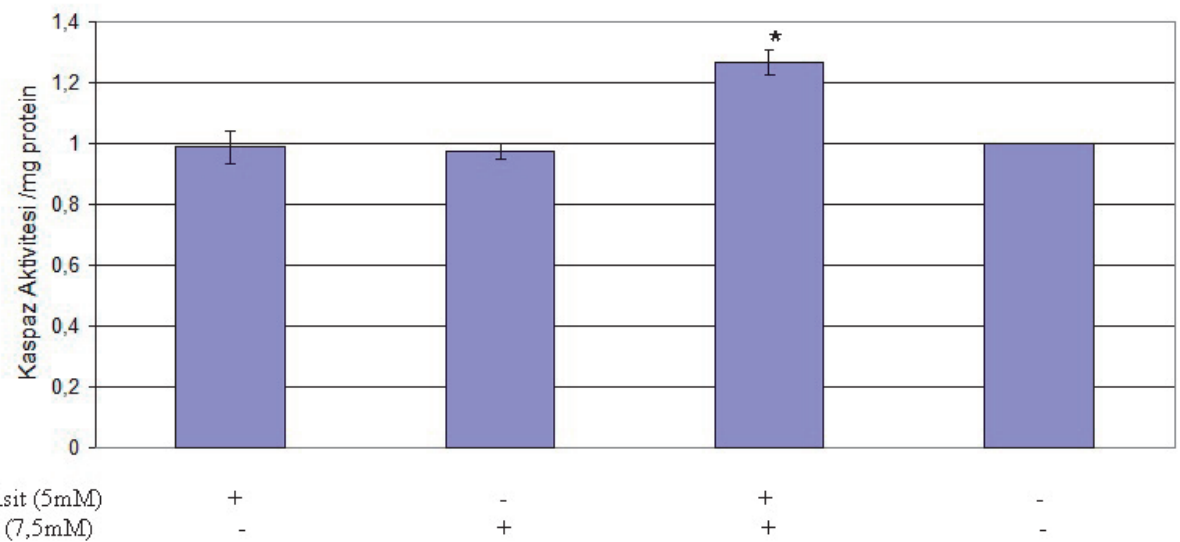

Şekil 4. HCT 116 -- hücre serilerinde $\alpha$ - lipoik asit ve L-karnitin' in kaspaz 3 enzim aktivitesi üzerindeki etkileri

\section{Tartışma}

Kolorektal karsinoma, batı ülkelerinde, kansere bağlı ölüm nedenlerinin ikinci sırasını oluşturmaktadır. Doğal ürünlerin, antitümör ilaçların geliştirilmesinde kritik roller oynadıkları ve onaylanmış antikanser ilaçların \%50'den fazlasının direk ya da indirek olarak doğal ürünlerden geliştirildiği bildirilmiştir (Mukherjee, 2001; Newman, 2012).

Epidemiyolojik çalışmalar, genetik faktörlere ek olarak, diyet ile ilgili faktörlerin de, kolon kanserine yatkınlıkta önemli rol oynadığını göstermiştir. İnsan diyetinde bulunan pek çok besinin antikarsinojenik özellikleri olduğu bilinir (Marques-Vidal, P., 2006). Bir aminoasit olan L-karnitin, besinlerde bulunan doğal bir bileşiktir ve vücutta lizin ve methionin aminoasitlerinden sentezlenir, antioksidan ve antikarsinojenik özelliklere sahiptir (Peluso,2000, Gulcin, 2006). $\alpha$-lipoik asit, doğal antioksidan lipofilik bir bileşiktir (Bilska, 2005). Kanser hücrelerinde, mesane, meme, kolon, hepatoma ve akciğer kanseri hücrelerinin proliferasyonunu, normal hücreleri etkilemeksizin baskılar (Feurecker, 2012, Yoo, 2013, Na, 2009, Michikoshi, 2013, Dozio, 2010, Schwartz, 2013). 
$\mathrm{Bu}$ çalışmada, insan diyetinde bulunan, L-karnitin ve $\alpha$-lipoik asitin kombinasyonunun, HCT $+/+$ ve HCT -/- kolon kanser hücrelerinin proliferasyonunun inhibisyonuna ve apoptozun indüklenmesine neden olup olmadıkları araştırılmıştır. Bu çalışmanın sonuçları, $\alpha$-lipoik asit ve L-karnitin'in kombinasyon halinde verildiklerinde, HCT +/+ ve -/- olmak üzere, her iki hücre serisinde de, hücrelerin canlılığında anlamlı derecede azalmaya neden olduklarını göstermiştir $(p<0,05)$. $\alpha$-Lipoik asit $(5 \mathrm{mM})$, tek başına uygulandığında, HCT $+/+$ ve -/- hücrelerin canlıllğında herhangi bir azalmaya neden olmamıştır. L-karnitin $(7,5 \mathrm{mM})$ ise +/+ hücrelerde canlılı̆̆ 1 tek başına azaltmazken, -/hücrelerin canlılığını tek başına azalttığı görülmüştür $(\mathrm{p}<0,05)$.

$\alpha$-lipoik asit ve L-karnitinin kombinasyonunun kullanılmasının amac1, olası antikarsinojenik etkinin sinerjetik olarak artıp atmayacağının belirlenmesidir. Tek başlarına verildiklerinde, bu çalışmada kullanılan dozlarda, kolon kanser hücrelerinin apoptozu üzerinde herhangi bir etki göstermezken, kombinasyonlarının hem HCT +/+ hem de -/- kolon kanseri hücre serilerinde p53 bağımlı ve bağımsız olarak, kaspaz 3 enzim aktivitesini artırdığı görülmüştür.

Sonuçlarımız, $\alpha$-lipoik asit ve L-karnitinin birlikte hücrelere birlikte uygulandığında, p53 bağımlı ve bağımsız olarak, HCT 116 +/+ ve -/- hücrelerin canlılığını azalttı̆̆1 ve apoptozunu artırdığını göstermiştir.

\section{Kaynaklar}

Behrend, L, Henderson, G., Zwacka, R.M. 2003. Reactive oxygen species in oncogenic transformation. Biochem Soc Trans, 31, 1441-1444.

Bilska, A., Włodek, L.2005. Lipoic acid - the drug of the future?. Pharmacol Rep. 57(5), 570-7.

Dozio, E., Ruscica, M., Passafaro, L., Dogliotti, G., Steffani, L., Marthyn, P., et al. 2010. The natural antioxidant alpha-lipoic acid induces p27(Kip1)-dependent cell cycle arrest and apoptosis in MCF-7 human breast cancer cells. Eur J Pharmacol. 641, 29-34.

Dörsam, B., Göder, A., Seiwert, N., Kaina, B., Fahrer, J. 2015. Lipoic acid induces p53-independent cell death in colorectal cancer cells and potentiates the cytotoxicity of 5-fluorouracil. Arch Toxicol, 89(10), 1829-46.

Feuerecker, B., Pirsig, S., Seidl, C., Aichler, M., Feuchtinger, A., Bruchelt, G., et al. 2012. Lipoic acid inhibits cell proliferation of tumor cells in vitro and in vivo. Cancer Biol Ther.13, 1425-35.

Fujii, Y., Segawa, R., Kimura, M., Wang, L., Ishii, Y., Yamamoto, R., Morita, R., Mitsumori, K., Shibutani, M. 2013. Inhibitory effect of $\alpha$-lipoic acid on thioacetamide-induced tumor promotion through suppression of inflammatory cell responses in a two-stage hepatocarcinogenesis model in rats. Chem Biol Interact, 205(2),108-18.

Gülçin, I. 2006. Antioxidant and antiradical activities of L-carnitine. Life Sci, 78: 803-811.

Hanahan, D., Weinberg Robert A. 2011. Hallmarks of cancer: the next generation. Cell,144 (5), 646-674. 
Huang,C.Y., Yu, L.C. 2015. Pathophysiological mechanisms of death resistance in colorectal carcinoma. World J Gastroenterol, 21(41), 11777-11792.

Mantovani, G., Maccio, A., Madeddu, C., Mura, L., Massa, E., Gramignano, G., Lusso, M.R., Murgia, V., Camboni, P., Ferreli, L. 2003. Reactive oxygen species, antioxidant mechanisms, and serum cytokine levels in cancer patients: Impact of an antioxidant treatment. $J$ Environ Pathol Toxicol Oncol, 22, 17-28. 9.

Marques-Vidal, P., Ravasco, P., Camilo, M.E. 2006. Foodstuffs and colorectal cancer risk: a review. Clin Nutr. 25, 14-36.

Michikoshi, H., Nakamura. T., Sakai, K., Suzuki, Y., Adachi, E., Matsugo, S., et al. 2013.AlphaLipoic acid-induced inhibition of proliferation and met phosphorylation in human non-small cell lung cancer cells. Cancer Lett. 335, 472-8.

Mizuno, M., Packer, L. 1994. Effects of alpha-lipoic acid and dihydrolipoic acid on expression of proto-oncogene c-fos. Biochem. Biophys Res Commun, 200,1136-1142.

Mukherjee, A.K., Basu, S., Sarkar, N., Ghosh, A.C. 2001. Advances in cancer therapy with plant based natural products. Curr Med Chem, 8 (12), 1467-1486.

Na, M.H., Seo. E.Y., Kim, W.K. 2009. Effects of alpha-lipoic acid on cell proliferation and apoptosis in MDA-MB-231 human breast cells. Nutr Res Pract. 3, 265-71.

Newman, D.J., Cragg, G.M. 2012. Natural products as sources of new drugs over the 30 years from 1981 to 2010. J Nat Prod,75 (3), 311-335.

Peluso G., Nicolai, R., Reda, E., Bennatti, P., Barbarisi, A., Calvani, M. 2000. Cancer and anticancer therapy-induced modifications on metabolism mediated by carnitine system. $J$ Cell Physiol. 182, 339-350.

Rochette, L., Ghibu, S., Richard, C., Zeller, M., Cottin, Y., Vergely, C. 2013. Direct and indirect antioxidant properties of alpha-lipoic acid and therapeutic potential. Mol Nutr Food Res, 57(1):114125.

Schwartz, L., Guais, A., Israel, M., Junod, B., Steyaert, J.M., Crespi, E., et al. 2013. Tumor regression with a combination of drugs interfering with the tumor metabolism: efficacy of hydroxycitrate, lipoic acid and capsaicin. Invest New Drugs. 31, 256-64.

Tenesa, A.D., Malcolm, G. 2009. New insights into the etiology of colorectal cancer from genome-wide association studies. Nat Rev Genet, 10 (6), 353-358.

Yoo, T.H., Lee, J.H., Chun, H.S., Chi, S.G. 2013. Alpha-Lipoic acid prevents p53 degradation in colon cancer cells by blocking NF-kappaB induction of RPS6KA4. Anticancer Drugs. 24, 555-65. 
